\title{
Importance of Social and Cultural Behavior of Korean Managers in the Slovak Republic - in Relation to Sustainable Development of Slovak Tourism
}

Dr. Peter Čuka ${ }^{1}$

\begin{abstract}
There are significant social and cultural differences between Slovaks and Koreans. Korean managers (of KIA Motors) living in Slovakia have specific requirements, expectations and behavior. In the field of tourism they prefer the classic geographical European destination - especially Germany, Austria, Switzerland and other countries. Their favorite Slovak destinations are High Tatra and Bratislava. The paper is oriented to evaluation of importance of social and cultural behavior of Korean managers and their impact in the sustainability Slovak tourism. The main aim of this paper is to evaluate access of the Koreas managers to Slovak culture, their efforts to learn the Slovak language, understanding the Slovak culture and their loyalty to visit the Slovak destinations as a one of ways to sustainable tourism.
\end{abstract}

Key words:Tourism, Sustainability, CulturalBehavior, SocialBehavior, KoreanManagers

\section{Introduction and Theoretical Foundations}

The study deals with the community of Koreans who live and work in Žilina. This community is very specific. It has different cultural, linguistic, economic, social and religious traditions from Slovaks. In Žilina lives and works about 450 Koreans. Major employer is Kia motors - producer of cars but also suppliers companies like SUNGWOO HITECH, Mobiš̌ilina, Kia Sales, and others. In Slovakia are also residing Korean Samsung in Galanta. Business and management positions are concentrated in Bratislava, too. In Žilina, we can identify three types of Korean communities:

a) The first is a community of managers and their families: this community lives in residential suburban district Krasñany. This community is highly isolated and the usual length of stay specified by corporate rules is four years.

b) The second is community of workers from various companies and small businesses in town - where they run restaurants and hairdresser's - usually residing in the city of Žilina.

c) The third community is more or less created by illegal workers. This community migrates across Europe, but due to the greater community of expatriates in Žilina they are also saturated in the city.

\section{Material and Methods}

The aim of the study is to highlight some of the socio - cultural differences of Koreans and Slovaks affecting their relationship. It also aims to outline the Koreans' demand for tourism in Slovakia and their opinion about the quality of tourist services.

| * PhD.,The Pedagogical University of Krakow, Instytut of Geography, ul. Podchorażzych 2, 30084 Krakow, Poland. 
The main method is personal contact with the Korean community and questionnaire.

Methods include also the sociological methods such as observation (Čuka, P. 2015; Denzin, K.N., Lincoln S. 2005), but also analysis of differences in geographical thinking (Nisbett, R, E. 2004), represented mainly in his monograph „,The Geography of Thought: How Asians and Westerners Think Differently... and Why".

Research is limited by the specificity of the Korean community. First, only a small fraction of them can speak Slovak. Despite long-term staying and Slovak courses, they mainly use English for communication with Slovaks. The main issue is to get relevant data from this community. Koreans are socially segregated community.

Given the rejection of the first type of research community (a - type - Kia Motors workers from Krasňany) to participate at the research, we conducted research among a small group of Korean Christians living in the city (b - type).

\section{Results of the Survey and Discussion}

The main results of the survey can be classified as follows:

a) Differences between Slovaks and Koreans in the area of Žilina

b) Mutual view of Slovaks to Koreans and vice versa

c) Travel preferences of Koreans

d) Proposals for the use of the Korean community in the development of sustainable tourism in Slovakia.

Differences between Slovaks and Koreans in the area of Žilina. Socio behavioral research had two levels. One was focused on the methods of interviews. The employees of KIA Motors were questioned a set of identical questions. We questioned Slovak workers (17 interviews). Later we used the same set of questions for Koreans workers of Kia Motors - (11 interviews). A set of questions contained these key information:

- How do you rate your knowledge of Koreans / Slovaks in a scale from 1 to 10 (10 for the highest level of knowledge, 1 for the lowest level of knowledge)

- What do you like / dislike about Koreans / Slovaks

- Where do you see the greatest differences / commonalities in the lives of Koreans / Slovaks

Of course we are aware that the two samples were not cognitively homogeneous in regard to the fact that Koreans living in Slovakia for a long term and no one from questioned Slovaks were in Korea. Therefore, knowledge of Slovak reality of Koreans is only empirical. For the same reason Slovaks do not know the Korean empirical realities, but their view of Koreans is similar to the view of autochthonous to allochthonous. Autochthonous and allochthonous relationship is in development and there are identified several phases (Przeclawki). The interviews have shown that the relationship between autochthonous and allochthonous (Slovaks vs Koreans) is more or less antagonistic. 
The Slovaks' level of knowing Koreans was from 8 - to 10; the Koreans' level of knowing Slovaks was rated from 5 to 8.

Slovaks like the best on Koreans their financial assessment of staff and the possibility of high earnings, while they dislike arrogance and physical punishments (only Koreans staff).

Koreans like the best on Slovaks sportsmanship; they do not like the food, poor service levels, lack of language training and repressive police.

Koreans evaluate differences similarly as Slovaks practically in the whole socio cultural spectrum. High proportion of Korean Christians does not change this fact.

In the second part of the survey we have distributed questionnaire (see Annex) to Korean Christians. Questionnaire was distributed to forty Christian Koreans; though return rate was only $30 \%$ (12 questionnaires). This also points to the incommunicativeness of the Korean community in Žilina.

The most important results of this part of survey are following:

- Respondents live in Slovakia for the long term - from 48 to 107 months,

- They all live there with their family or some family members,

- The diversity of Slovakia is considered as seasonality (natural and climatic),

- The most popular is the natural potential of Slovakia (11 responses out of 12),

- Some Slovak specificalities are evalued positively (noodles, other food and beverages),

- The shortcomings are the following: Slovak "slowness" (6 responses), restrictive police ( 7 responses), poor services and infrastructure (8 responses),

- Regarding their knowledge of Slovakia: Bratislava and High Tatras (6 responses), Piešt'any (5 responses); Koreans know especially Zilina and its surroundings e. g. Rajecké Teplice and Terchová (7 responses)

- 9 out of 11 responses refer to the foreign tourism. Thus, Koreans use the stay in Slovakia mostly for working reasons; 10 out of the 12 responses refers that they spend holidays mostly abroad, mainly in Germany, Austria, Switzerland and Poland.

Sustainable tourism in Slovakia is rooted in a number of documents (Huba,M. Hudek,V. 2004). One option is to redirect the relatively rich even if no sizeable Korean clients to Slovak spas and use targeted marketing to make more accessible the most significant cultural and natural monuments of Slovakia (UNESCO). The greatest potential for Korean clients has High Tatras, region of MaláFatra and spa towns, especially Rajecké Teplice, Turčianske Teplice and Piešt'any.

\section{Conclusion}

South Korea and the Slovak Republic are geographically, demographically, socially, culturally and economically very different country. South Korea has more than twice the size of Slovakia, more than ten times of inhabitants and GNP if we count the 
EU as a single market is the ninth in the world and fourth in Asia (http://www.mhsr.sk/). GNP per capita is in South Korea about 25 thousands USD/inhabitant, Slovakia about 26 thousand USD/inhabitant (http://www.tradingeconomics.com/). Although Slovakia has a higher GNP per capita, but the average monthly wage in Korea is roughly three times higher (http://dennik.hnonline.sk/ekonomika-a-firmy...). High income disparities between Slovak workers at Kia Motors Ltd. create inequalities in social relations. On the other hand, however, it creates a group of affluent clients in the Korean clients in Slovak tourist market.

\section{Research Questionnaire}

1. Howlonghaveyoubeen in Slovakia? Writethenumberofmonths:......

2. Are you in Slovakia withyourfamily?

3. Whatisyourknowledgeof Slovak language?

Excellent; verygood; good; poor;none

4. Howwell do youknow Slovakia?

Excellent; verygood; good; poor;none

5. What do youlikebest in Slovakia?

6. What do youfindverydifferent in Slovakia (compared to Korea)

7. What do youfindsimilar in Slovakia?

8. What do youdislike most in Slovakia?

9. How do youspendyourleisuretime?

- With my family

- Going to town,

- Wego to nature,

- Sports,

- Visits to culturalevents,

- Shopping,

- Other.

10. Didyouspentyourholiday in Slovakia? (writehowmanytimes)

11. Wheredidyouspendvacation in Slovakia?

12. Which Slovak regions do youknow?

13. Which Slovak monuments (including UNESCO) do youknow?

14. Which Slovak naturereserves do youknow?

15. Which Slovak spatowns do youknow?

16. Whatactivities do youprefer on yourvacation (holiday)?

- familyholiday

- Outdoor 
- Sports

- Exploringnature

- Culture

- Wellness and Spa

- Others:

17. How do youassessthequalityoftouristservices in Slovakia? excellent, verygood, good, weak

18. What do weneed to improveregardingthequalityofservices in Slovakia?

19. How do youevaluatethecostoftouristservices in Slovakia?

- Pricesofaccommodation:

- Pricesoffood and beverages:.

- Pricesofotherservices:

20. Do yougo on holidayabroadduringyourstay in Slovakia?

21. Whichregions in Slovakia do youplan to visit?

22. Whichcountrieshaveyouvisitedexcept Slovakia?

23. Whichregions (except Slovakia) do youwantvisitduringyourstay in Slovakia? Namethecountries and regions:

\section{References}

ČUKA,P., KRUCZEK, Z., SZROMEK, A. 2015. Observationas a basicqualitativemethod in tourismresearch - case study oftouristdestination Donovaly in Slovakia. In: 15th SGEM ConferenceBulgaria, Albena;Informatics, Geoinformatics and RemoteSensing, s. 761 - 767. ISBN 978- 619- 7105- 34- 6.

DENZIN, K.N., LINCOLN S. 2005. The Sage Handbook of Quantitative research, 3 td Edition. Sage Publications London, Thousand Oaks and New Delhi, Sage Publications Inc. ISBN 9781412974172.

NISBETT, R, E. 2004. The Geography of Thought: How Asians and Westerners Think Differently...and Why. Free Press USA, ISBN 0-7432-1646- 6.

PRZECLAWSKI,K. 2004. Czlowiek a turystyka. Zarys socjologii turystyki. Albis, FHU Kraków ISBN 83906452-0-3.

PRZECLAWSKI, K. 1993. Tourism as a subject of interdisciplinary research. In:Tourism Research: Critiques and Challenges. [ed.] Pearce, D.G. \& Butler, R.W., Routledge, p. 9-19.

HUBA, M., HUDEK, V. a kol. 2001. Trvaloudržatel’nýrozvoj - výzva pre Slovensko. 1. vyd. Bratislava: REC Slovensko, K\&K Topografia. 127 s. ISBN 80-968591-7-X.

http://dennik.hnonline.sk/ekonomika-a-firmy/479312-v-korei-zarabaju-ludia-ako-nasi-manazeri

http://www.mhsr.sk

http://www.tradingeconomics.com 